\title{
КОМПЛЕКСНІ ПОРУШЕННЯ РОЗВИТКУ В ДІТЕЙ: НАУКОВІ ПІДХОДИ ТА ПСИХОЛОГІЧНІ ОСОБЛИВОСТІ
}

\author{
Шевчук В. В., Клименко Ю. О.
}

\section{ВСТУП}

Станом на 1 січня 2020 р. в інклюзивних класах України навчаються 19345 учнів із особливими освітніми потребами. Ця кількість у сім разів перевищує дані п’ятирічної давнини. На початок 2020 р. в Україні створено 13782 інклюзивні класи. Так, у 2019-2020 навчальному році $35 \%$ від загальної кількості закладів загальної середньої освіти організували інклюзивне навчання. У закладах дошкільної освіти станом на 1 січня 2020 р. перебуває 4681 вихованець із особливими освітніми потребами. Також із 2019-2020 навчального року інклюзивне навчання запроваджено в закладах професійної, професійно-технічної та вищої освіти, де навчаються 1312 здобувачів 3 особливими освітніми потребами ${ }^{1}$.

Більше 151000 дітей 3 інвалідністю в Україні потребують регулярної допомоги. Серед причин інвалідності у дітей на I місці вроджені аномалії, деформації та хромосомні порушення (30\%), на II - хвороби центральної нервової системи (17,9\%), на III - розлади психіки та поведінки (13,9\%). У віковій структурі дітей з інвалідністю основну групу становлять діти шкільного віку від 7 до 14 років (більше 49\%), на другому місці - у віці від 15 до 17 років (більше 23,7\%), на третьому - від 3 до 6 років (близько $20 \%)^{2}$.

Конвенція про права осіб з інвалідністю (2006), Закони України «Про внесення змін до Закону України «Про освіту» щодо особливостей доступу осіб з особливими освітніми потребами до освітніх послуг» від 23 травня 2017 р., «Про внесення змін до деяких законів України про освіту щодо організації інклюзивного навчання від 5 червня 2014 р., «Про ратифікацію Конвенції про права осіб 3 інвалідністю і Факультативного протоколу до неї від 16 грудня 2009 р., Укази Президента «Про заходи, спрямовані на забезпечення додержання прав осіб з інвалідністю» від 13 грудня 2016 р., «Про заходи щодо розв'язання актуальних проблем осіб з обмеженими фізичними можливостями» від 19 травня 2011 р., Постанови Кабінету

1 Статистичні дані. Міністерство освіти і науки України - MOH. URL: mon.gov.ua〉statistichni-dani.

${ }^{2}$ Дитячі проблеми. URL: http://uwcfoundation.com/ua/detskie-problemyi. 
Міністрів України «Про внесення змін до Порядку організації інклюзивного навчання у загальноосвітніх навчальних закладах» від 9 серпня 2017 р., «Про затвердження Положення про інклюзивноресурсний центр» від 12 липня 2017 р. тощо визначають забезпечення прав дітей із обмеженими психофізичними можливостями.

Серед вихованців, що мають особливі освітні потреби, дослідниками Н. Александровою, 3. Алієвою, Ю. Антибурою, Г. Аристовою, Т. Басиловою, Г. Бертинь, М. Блюміною, М. Вернадською, Л. Виготським, Т. Власовою, Н. Гладких, Л. Головчиц, Л. Григор'євою, М. Давидовим, М. Жигорєвою, Н. Зінов’євою, І. Катковою, О. Каракуловою, К. Козловою, В. Лубовським, О. Мастюковою, Н. Медовою, А. Мещеряковим, I. Молчановською, О. Московкіною, А. Набичевою, Д. Науменко, М. Певзнер, Л. Переслені, Л. Рожковою, Т. Розановою, Н. Сошниковою, І. Філатовою, Л. Фільчиковою, В.Чулковим, Л. Яковлевою, D. Boas, L. Ferreira, A. Marzouq, M. Moura, S. Maia, I. Amaral, M. Janssen, D. Moores, J. Van Dijk та іншими виділено категорію дітей із множинними або комплексними вадами розвитку. Такі порушення розвитку можуть також називатися «складними сенсорними», «бісенсорними», «потрійними», «провідними порушеннями із супутніми», «ускладненими», а основою їх визначення $\epsilon$ поліморфний характер вад розвитку. У разі патологій окремі порушення зберігають свої особливості, але виникає якісно новий варіант розвитку дитини.

\section{1. Основні наукові підходи до класифікації}

\section{порушеного розвитку дітей}

Порушенням $\epsilon$ функціональне обмеження індивіда, спричинене фізичними, інтелектуальними чи сенсорними вадами. I. Іванова, В. Ілюхіна, М. Кошулько під порушенням розуміють втрату чи аномалію психологічної, фізіологічної чи анатомічної структури або функції․

Згідно з Міжнародною класифікацією функціонування, обмеження життєдіяльності і здоров'я порушення - це проблеми, що виникають у функціях або структурах, такі як істотне відхилення або втрата. Порушення можуть означати аномалію, дефект, втрату чи інше значне відхилення у структурах організму. Біологічні основи порушень у класифікації є провідними, поряд із цим може існувати можливість розширення класифікації на клітинному або молекулярному рівнях. Порушення - це відхилення від певних загальноприйнятих стандартів біомедичного статусу організму та його функцій; визначення їхніх складових частин здійснюється насамперед спеціалістами, котрі

3 Иванова Т.Б., Илюхина В.А., Кошулько М.А. Диагностика нарушений в развитии детей с ЗПР. Санкт-Петербург : Детство-Пресс, 2011. 112 с. 
оцінюють фізичне та психічне функціонування відповідно до цих стандартів. Порушення можуть бути тимчасовими чи постійними; прогресуючими, регресуючими або стабільними; переміжними або безперервними. Відхилення від норми може бути незначним або суттєвим і змінюватися з часом. Порушення не залежать від етіології чи способу їх розвитку; наприклад, втрата зору або кінцівки може виникнути внаслідок генетичної аномалії або травми. Наявність порушення обов'язково передбачає причину, однак причина може бути недостатньою, щоб пояснити отримане порушення. Наявність порушення також указуе на наявність функціонального або структурного розладу організму, але він може бути зумовленим будьяким захворюванням, розладом або фізіологічним станом. Порушення можуть бути частиною або проявом стану здоров'я, але вони не обов'язково означають наявність захворювання, або ж особа повинна вважатися хворою. Порушення $\epsilon$ ширшими та більш комплексними, ніж розлади або хвороби; наприклад, втрата кінцівки - це порушення структури організму, але не розлад чи хвороба. Одні порушення можуть спричиняти інші розлади; наприклад, втрата м'язової сили може погіршити рухові функції; функції серця можуть бути пов'язані 3 порушенням дихальної функції, а порушення сприйняття може бути пов'язане з функціями мислення.

Деякі категорії Міжнародної класифікації функціонування, обмеження життєдіяльності та здоров'я частково збігаються 3 категоріями МКХ-10, особливо щодо симптомів і ознак. Проте ці дві класифікації мають різні цілі. Для реєстрації захворюваності та звернення за послугами МКХ-10 у спеціальних розділах класифікує симптоми, тоді як МКХ відображає їх як частину функцій організму, що може бути використана для профілактики або визначення потреб пацієнтів. Найбільш важливим $є$ те, що МКХ передбачає використання класифікації функції та структури організму спільно 3 категоріями «активність» та «участь». Порушення класифікують у відповідних категоріях із використанням визначених критеріїв ідентифікації, таких як: втрата чи відсутність; зниження; збільшення або надлишок; відхилення. Як тільки порушення з'являється, його можна оцінювати за ступенем тяжкості з використанням загального кваліфікатора МК $\Phi^{4}$.

Термін «складне порушення» використовують для позначення поєднання олігофренії із сенсорними порушеннями чи порушеннями опорно-рухового апарату. Особливостям розвитку дітей із такими

\footnotetext{
${ }^{4}$ Наказ МО3 України № 981 від 23 травня 2018 р. «Про затвердження перекладу Міжнародної класифікації функціонування, обмежень життєдіяльності та здоров'я та Міжнародної класифікації функціонування, обмежень життєдіяльності та здоров'я дітей і підлітків». URL: http://search.ligazakon.ua/1_doc2.nsf/link1/ MOZ30749.html.
} 
порушення присвячені дослідження 80-90-х рр. ХХ ст. Т. Басілової, Г. Бертинь, М. Блюміної, О. Мастюкової, Н. Олександрової, M. Певзнер, Т. Розанової, В. Чулкова, M. Janssen, D. Moores, J. Van Dijk. У цей період на базі науково-дослідного інституту дефектології АПН СРСР було проведено клініко-психолого-педагогічне вивчення дітей, котрі мали поєднання глухоти та легкої розумової відсталості, недоліки зору, порушення опорно-рухового апарату. На основі цього для позначення поєднання різноманітних первинних порушень почали використовувати термін «складне порушення». За Т. Басіловою та Н. Олександровою, складне або множинне порушення - це порушення двох і більше систем організму первинного характеру в однісї дитини 3 комплексом вторинних відхилень. Наприклад, слабозорість і рухові порушення, сліпоглухота, сліпота і порушення мовлення, порушення інтелекту з вираженими порушеннями зору та слуху тощо 5 . В. Чулков складними порушеннями дитячого розвитку вважав поєднання двох і більше психофізичних порушень в однісї дитини. Наприклад, поєднання глухоти та слабозорості, порушення інтелекту, опорнорухового апарату та мовлення ${ }^{6}$. Г. Бертинь, Л. Головчиц, O. Мещеряков, I. Соколянський, J. Van Dijk вважали складним порушенням специфічно цілісний феномен, який характеризує особливу ситуацію розвитку дитини. М. Блюміна складними вважала порушення, за яких спостерігається два чи більше первинні порушення, i кожне існує в цьому комплексі з характерними для нього вторинними відхиленнями, що ускладнюють загальну структуру порушення та затримують його компенсацію. За характером прояву різних порушених функцій дослідниця виокремлювала такі типи поєднання порушень, які $€$ в однієї дитини: наявність одного порушення призводить до вторинних і третинних порушень (порушення слуху викликає вторинне недорозвинення мовлення та відставання інтелектуального розвитку); одні порушення ускладнюють прояви інших (олігофренія, ускладнена руховими порушеннями) ${ }^{7}$. Т. Басілова, Г. Бертинь, О. Мастюкова, М. Певзнер, Т. Розанова вважали складними порушеннями поєднання двох i більше первинних психофізичних порушень, що однаковою мірою визначають структуру аномального розвитку та складності у соціальній адаптації дитини. Такі порушення зумовлюють відхилення від нормального розвитку та пов'язані 3 порушеннями різних систем. Серед складних порушень домінують

5 Басилова Т.А., Александрова Н.А. Как помочь малышу со сложным нарушением развития. Москва : Просвещение, 2008. С. 20.

6 Чулков В.Н. Развитие и образование детей со сложными нарушениями развития. Специальная педагогика : учебное пособие / под ред. Н.М. Назаровой. Москва : Academia, 2000. C. 338.

7 Блюмина М.Г. Распространенность, этиология и некоторые особенности клинических проявлений сложных дефектов. Дефектология. 1989. № 3. С. 4. 
вроджені форми патології, які мають переважно генетичне походження. Т. Басілова виділяла близько двадцяти типів складних і множинних порушень, представлених поєднанням первинних сенсорних, рухових, мовленнєвих, емоційних порушень, а також поєднаннями цих порушень із олігофренією різного ступеня ${ }^{8}$.

Подвійні сенсорні порушення, як поєднання вад слуху та зору, досліджували Г. Бертинь, Р. Марєєва, О. Мещеряков, Н. Олександрова, M. Певзнер, Т. Розанова, I. Соколянський. Тривалий час ішлося переважно про сліпоглухонімих дітей (Р. Марєєва, О. Мещеряков, I. Соколянський). Нині в такому терміні не доцільно, на думку Н. Гладких, використання вторинного відхилення - німоти. Зазвичай виокремлення таких груп дітей було зумовлено необхідністю вибору окремого навчання, оскільки вони не могли навчатися в існуючих типах шкіл. Так, сліпоглухими вважалися діти, які за станом зору не могли навчатися у школі для глухих, а за станом слуху - у школі для сліпих. Пізніше, у 90-х рр. минулого століття, у структурі подвійних сенсорних порушень почали визначати лише первинні. Дітей із порушеннями зору та слуху почали називати сліпоглухими, а термін «сліпоглухонімий» зараз вважається застарілим. Поступово до такої групи синонімічно почали використовувати термін «подвійні сенсорні порушення», що означає поєднання виражених різною мірою порушення слуху та зору9.

У дослідженнях Т. Басілової, Г. Бертинь, О. Катаєвої, Р. Марєєвої, М. Певзнер, В. Чулкова використовується термін «потрійне порушення», що означає поєднання вад слуху, зору, інтелекту, мовлення або опорно-рухового апарату. О. Мещеряков і Т. Розанова відзначали, що психічний розвиток за подвійного чи потрійного порушення не зводиться до суми особливостей психічного розвитку за кожного порушення, а утворює нову, складну структуру порушень і потребує особливого психолого-педагогічного підходу ${ }^{10}$. Окрім поняття «складного», «бісенсорного» та «потрійного» порушення, $\epsilon$ «провідне порушення із супутніми чи додатковими», яке передбачає одне основне порушення, що виражене більшою мірою, та менш виражене додаткове (супутне). Для вітчизняного наукового вжитку термін «супутні» є більш доречним, але він може вживатися тоді, коли йдеться про неглибоке порушення, яке $\epsilon$ ускладненим. Використання таких словосполучень $є$ недоречним щодо, наприклад, глухої дитини 3 олігофренією, коли інтелектуальне порушення не може розглядатися як

${ }^{8}$ Гладких Н.В. Актуальні проблеми навчання та виховання дітей 3 комплексними порушеннями розвитку в Україні. Науковий часопис імені М.П. Драгоманова. Серія 19. Корекиійна педагогіка та спеиіальна психологія. 2014. № 26. С. 53.

${ }^{9}$ Там само. С. 52-57.

${ }^{10}$ Розанова Т.В. Методы психолого-педагогического изучения глухих детей со сложным дефектом. Дефектология. 1992. № 2-3. С. 5-11. 
супутнє, а впливає на розвиток дитини такою ж мірою, як і порушення слуху, а іноді й більшою.

На поширення такої неоднозначної термінології мали вплив праці зарубіжних авторів, наприклад, 3 англійської «additional» означає додатковий, а в українській мові - «супутній». D. Moores визначав, що особливу категорію становлять глухі діти 3 супутніми порушеннями, які складно виявити, але ще складніше створити для таких дітей адекватні умови виховання та навчання ${ }^{11}$. А. Marzouq відзначав, що у глухих дітей частіше зустрічаються супутні порушення, ніж у інших, а порушення інтелекту може залишитися довго не виявленим, оскільки, наприклад, туговухість, поєднана з інтелектуальним порушенням, може бути ідентифікована як глухота, а зниження зору у глухих дітей часто залишається непоміченим ${ }^{12}$. J. Van Dijk відмічає складності відмежування впливу інтелектуальних i сенсорних порушень на психічний розвиток дитини, і тому до особливої групи він зараховує дітей із труднощами у навчанні та порушеннями поведінки. Найчастіше серед глухих зустрічаються діти 3 порушеннями мовлення, глухі діти 3 емоційними та поведінковими порушеннями ${ }^{13}$.

Таким чином, глуха дитина 3 «додатковими» порушеннями має одне провідне порушення та супутні захворювання, котрі перешкоджають їі нормальному розвитку.

Наступний термін, яким користуються для позначення комплексу кількох вад розвитку дитини, є «ускладнене порушення». Наявність у дитини 3 первинним сенсорним або інтелектуальним порушенням легких розладів опорно-рухового апарату чи поведінки часто трактується як «складне порушення». Це ускладнює диференціацію термінів «супутнє» й «ускладнене порушення». За «ускладненого порушення» наявні два первинні порушення, одне 3 яких виражене більшою мірою, а інше - меншою. Н. Гладких не погоджується з цим терміном, оскільки одне порушення поєднується 3 іншим легкою мірою. Наприклад, у цьому типі йдеться про глухоту або зниження слуху, які ускладнені не грубими руховими чи зоровими розладами, неврологічною патологією або психопатологічними розладами, соматичними захворюваннями. У клініко-психолого-педагогічних дослідженнях О. Кукушкіної та О.Гончарової підкреслюється негативний вплив на психічний розвиток дитини ускладнених

${ }^{11}$ Moores D.F. Education the deaf: psychology, principles and practices. Boston, 1987. $143 \mathrm{p}$.

12 Marzouq A.A. The Importance of Teachers' Universal Design for Transition Principles Knowledge in Preparing Students Who Are Deaf and Hard of Hearing for the Life after School in Saudi Arabia. Creative Education. 2018. Vol. 9. № 3.

${ }^{13}$ Van Dijk J., Janssen M. Deafblind children. In H. Nakken (Ed.), Meervoudig gehandicapten. Rotterdam : Lemniscaat, 1993. P. 34-73. 
порушень, збільшення вторинних відхилень, що призводять до відставання в соціальному, пізнавальному та мовленнєвому розвитку ${ }^{14}$.

Розуміння структури «ускладненого порушення» трактується М. Жигорєвою та О. Мастюковою як порушення, яке передбачає наявність двох первинних порушень, одне з яких визначає структуру порушення, оскільки зумовлює вторинні відхилення, а інші - первинні порушення, що слабо виражені та не призводять до негативних наслідків і не впливають на провідне порушення. За умови раннього виявлення та надання комплексної допомоги такі первинні порушення компенсуються.

Прикладом ускладненого порушення може бути глухота 3 легкими опорно-руховими порушеннями. Ускладнене порушення характеризується виділенням провідного порушення і розладів, які його ускладнюють. Наприклад, у дитини 3 порушеннями розумового розвитку можуть спостерігатися не різко виражені порушення зору, слуху, опорно-рухового апарату, емоційні та поведінкові розлади. Провідне й ускладнювальне порушення можуть мати характер пошкодження, недорозвинення або їх поєднання. Ускладненим порушенням може бути поєднання рухових і поведінкових розладів, які розглядаються як симптоми ускладненої олігофренії внаслідок перинатального ураження ЦНС. Результатом перенесеного в ранньому віці менінгіту може стати глухота, ускладнена гідроцефалією й епілепсією або амбліопією чи косоокістю. Діти 3 ускладненим порушенням зазвичай можуть успішно навчатися разом із дітьми, котрі мають аналогічне провідне порушення, для них немає необхідності створювати особливі програми та добирати методи навчання, достатньо індивідуального підходу, який буде враховувати їх особливості.

Термін «множинні порушення» використовується для визначення поєднання трьох і більше виражених порушень розвитку. До них можна віднести комплекс сенсорних і рухових порушень в однієї дитини, викликаних глибоким ураженням ЦНС. Такими порушеннями можуть бути вади зору та ДЦП, глухоти та ДЦП, сліпоглухота, сліпота i туговухість, сліпота та системне порушення мовлення, розумова відсталість і виражене порушення зору, знижений зір і глухота, знижений зір із глухотою i порушенням руху тощо. У зарубіжних дослідженнях часто використовується термін «multiple disability», що означає наявність у дитини кількох психофізичних порушень: порушення інтелекту та сліпоти, порушень інтелекту й опорнорухового апарату чи інших поєднаних порушень. Зазначимо, що

14 Гладких Н.В. Актуальні проблеми навчання та виховання дітей 3 комплексними порушеннями розвитку в Україні. Науковий часопис імені М.П. Драгоманова. Серія 19. Корекиійна педагогіка та спеціальна психологія. 2014. № 26. C.52-57. 
використання дослівного перекладу використовуваного в англомовній літературі терміна буде недоречним, оскільки українською мовою він також звучатиме як «множинне порушення». Як відомо, у вітчизняній спеціальній літературі він використовується на позначення трьох i більше порушень психофізичного розвитку, виражених різною мірою. Ще більшою помилкою, з погляду наукової термінології, як вважає Н. Гладких, $є$ назва «мультидефект» ${ }^{15}$.

У зарубіжній літературі відзначається відхід від «handicap» («дефект», «порушення») на користь терміна «disability» («неспроможність», «відсутність можливості»). Рідше використовуються терміни «handicapped children», «severely profoundly handicapped» для позначення дітей зі поєднанням порушень сенсорного та інтелектуального розвитку, тяжких рухових розладів, а частіше вживаються аналоги, які складно дібрати в українській мові - «complex impairments» (комплексні порушення), «multiply impairments» (множинні порушення), «additional disabilities» (додаткові порушення) $)^{16}$, тоді як пряме значення слова «impairment» найближче до українського слова «ураження».

Діти зі складними множинними, тобто комплексними порушеннями розвитку - це діти, у яких унаслідок вродженої недостатності чи набутого органічного ураження сенсорних органів, опорно-рухового апарату або центральної нервової системи розвиток відхиляється від нормативного. Вони потребують спеціальних умов навчання і виховання. М. Жигорєва та І. Левченко наводять такі визначення поліморфних порушень розвитку: складні (комплексні) порушення $\epsilon$ кількома первинними порушеннями, кожне з яких, будучи окремим, визначило б характер і структуру порушеного розвитку, а всі складові елементи комплексного порушення перебувають у взаємодії та мають негативний ефект; ускладнений дефект мають кілька первинних порушень, одне $з$ яких є провідним і визначає структуру порушеного розвитку; множинні порушення, за яких у дитини одночасно існують три та більше первинні порушення, причому кожне має негативні наслідки, наприклад, розумово відсталі та сліпоглухі ${ }^{17}$.

Таким чином, термін «множинне порушення» може використовуватися i для позначення поєднання двох первинних порушень, будучи синонімом терміна «складне порушення». Також під складними множинними порушеннями розвитку розуміється комплексний синдром, частиною якого $є$ порушення інтелектуального

${ }^{15}$ Там само. C. 52-57.

${ }^{16}$ Boas D.C., Ferreira L., Moura M., Maia S., Amaral I. Analysis of interaction and attention processes in a child with multiple disabilities. Audiology - Communication Research, 2017, 12. URL: https://doi.org/10.1590/2317-6431-2016-1718.

17 Жигорева М.В., Левченко И.Ю. Дети с комплексными нарушениями развития: Диагностика и сопровождение. Москва : Национальный книжный центр, 2016. 208 с. 
розвитку в поєднанні з порушеннями зору, слуху, фізичного розвитку і труднощами у вихованні.

Згідно зі стандартами ВООЗ порушення психофізичного розвитку можуть мати легку, середню, важку i дуже важку форми. Розповсюдженим $\epsilon$ практико-орієнтований критерій, що визначає форму порушення на підставі обсягу допомоги, яку необхідно надати особі з вадами розвитку. Відповідно до цього розрізняють малу, середню, велику і дуже велику потребу в допомозі.

Говорячи про складні форми порушень психофізичного розвитку, найчастіше мають на увазі численні вади відчуттів, когнітивної, емоційновольової, тілесної структури особистості, а також соціальні та комунікативні здібності, всі засоби самовираження. Йдеться про порушення, що зачіпають всю особистість, усі сфери їі життєдіяльності: такі особи не в змозі самостійно встановлювати різні види відносин із навколишнім світом, вони значною мірою потребують догляду за собою і допомоги в побуті. А. Царьов зазначає, що основним у клінічній картині складного та множинного порушення $\epsilon$ розумова відсталість у різних поєднаннях із руховими порушеннями (ДЦП різної форми i міри тяжкості); складними порушеннями мовлення (несформованістю мовних засобів); порушеннями функцій аналізаторних систем (зору, слуху, тактильної чутливості); підвищеною судомною готовністю (епісиндромом); розладами емоційно-вольової сфери (порушенням регуляції поведінки тощо); аутистичними розладами (стереотипними діями, порушенням комунікації, соціальної поведінки) ${ }^{18}$.

Згідно 3 даними Н. Назарової сучасні дослідники залежно від структури порушення поділяють дітей на три основні групи: діти 3 двома вираженими психофізичними порушеннями, кожне 3 яких може викликати порушення розвитку, наприклад, сліпоглухі, розумово відсталі глухі, слабочуючі з первинної затримкою психічного розвитку тощо; діти, які мають одне провідне та слабко виражене супутнє психофізичне порушення, що може помітно обтяжувати розвиток (наприклад, розумово відсталі діти з незначним зниженням слуху), у таких випадках говорять про «ускладнений» дефект; діти 3 так званими «численними порушеннями», коли є три та більше первинні порушення, які виражені різною мірою та призводять до значних відхилень у розвитку дитини, наприклад, розумово відсталі слабозорі глухі діти ${ }^{19}$.

Л. Головчиц, М. Жигорєва, І. Саломатіна для характеристики дітей, котрі мають декілька первинних порушень, дедалі частіше

18 Обучение детей с тяжелыми и множественными нарушениями развития: Программы / под ред. А.М. Царева. Псков, 2004. 132 с.

19 Модель комплексного сопровождения детей с тяжелыми множественными нарушениями развития, в том числе с расстройствами аутистического спектра : методическое пособие / авт.-сост. И.А. Филатов, Е.В. Каракулова. Екатеринбург : УГПУ, 2017. 287 c. 
використовують терміни «комплексні» або «комбіновані порушення». Для позначення групи розладів, за яких поєднуються два і більше первинні порушення розвитку, ми пропонуємо використовувати термін «комплексне порушення». Цей термін може розповсюджуватися і на різні варіанти комбінованого порушення, а також на множинні порушення. Він може вживатися для позначення дітей із глибокими порушеннями слуху і зору; різноманітними варіантами поєднання сенсорних, інтелектуальних, рухових порушень, розладів емоційно-вольової сфери та ін.

Термін «комплексні порушення розвитку», на нашу думку, є найбільш влучним терміном, що повністю визначає структуру порушення, оскільки i первинні порушення у структурі цих порушень, і викликані ними вторинні відхилення доцільно розглядати цілісно, у комплексі ${ }^{20}$.

Грунтуючись на аналізі наукових досліджень 3 окресленої проблеми, М. Жигорєва пропонує таке визначення: «до комплексних порушень належать представлені декількома первинними порушеннями, кожне з яких є окремим, визначає характер і структуру аномального розвитку. Усі порушення мають багатоаспектний вплив і взаємопідсилюються. Як наслідок, негативний прояв таких дисфункцій $є$ кількісно і якісно набагато грубішим порівняно із простим додаванням окремих порушень».

\section{2. Психологічні особливості}

\section{дітей із комплексними порушеннями розвитку}

Характеризуючи особливості «аномального розвитку», Л. Виготський зазначав, що дитина, розвиток якої ускладнений порушенням, не просто менш розвинена, ніж іiі нормальний одноліток, - вона $\epsilon$ дитиною, у якої якісно інший розвиток. 3 огляду на те, що у дитини $з$ комплексними порушеннями є кілька первинних порушень, розвиток такої дитини є якісно своєрідним типом розвитку. Згідно 3 положенням Л. Виготського важливою закономірністю порушеного розвитку дитини є співвідношення первинного порушення i вторинних відхилень. У дитини 3 комплексними порушеннями первинних «дефектів» декілька, кожен із яких має вторинні відхилення, ускладнюючи їх і зумовлюючи відхилення третього порядку ${ }^{21}$.

Отже, процес розвитку дітей із комплексними порушеннями розвитку можемо розглядати лише на основі детермінованості особливостей усіх факторів, що відображаються впливом тієї чи іншої патології. Важливо виявити характер первинних порушень та

20 Гладких Н.В. Актуальні проблеми навчання та виховання дітей 3 комплексними порушеннями розвитку в Україні. Науковий часопис імені М.П. Драгоманова. Серія 19. Корекиійна педагогіка та спеціальна психологія. 2014. № 26. С. 52-57.

21 Выготский Л.С. Проблемы дефектологии. Москва : Просвещение, 1995. C. 127. 
особливості їхнього впливу на формування вторинних відхилень, які визначають своєрідність психічного розвитку дитини. Структура вторинних відхилень залежить від характеру провідного порушення. Вторинні порушення розвитку зачіпають насамперед мовлення, дрібну моторику, просторові уявлення, довільну регуляцію діяльності тощо.

Г. Бертинь, К. Глущенко, Н. Гладких та І. Лукашева відзначають, що фізичний i психічний розвиток у дітей із комплексними порушеннями набагато відстає від дитини у нормі. Однією з найбільш складних категорій комплексних порушень розвитку, на думку Н. Гладких, є діти з поєднанням порушень опорно-рухового апарату, інтелекту та зору, що зумовлює необхідність диференційованого підходу до їхньої психолого-педагогічної корекції. Така категорія дітей $\epsilon$ складною через важкість порушень розвитку та їхніх вторинних відхилень, які, пов'язуючись між собою, утворюють складну структуру порушення. Специфічні особливості розвитку дітей із комплексними порушеннями розвитку мають загальні риси, які дозволяють розділити дітей на три групи (за А. Царьовим):

I) діти зі складними порушеннями опорно-рухового апарату, котрі самостійно не пересуваються (складні форми ДЦП, спастичний тетрапарез, гіперкінез тощо). Такі діти потребують постійної фізичної допомоги дорослих при перенесенні, пересуванні візочка, одяганні та роздяганні, туалеті, прийомі їжі тощо. Більшість таких дітей не можуть самостійно утримувати своє тіло в сидячому положенні. Спастичність кінцівок часто ускладнена гіперкінезами. Процес спілкування також утруднений через несформованість мовних засобів. Інтелектуальний розвиток таких дітей різний. Ступінь розумової відсталості коливається від легкої до глибокої. Діти цієї групи 3 менш вираженим інтелектуальним недорозвиненням мають передумови для формування уявлень, умінь і навичок, які є значущими для соціальної адаптації. Більшість дітей проявляє інтерес до спілкування і взаємодії, що дозволяє навчати їх користування невербальними засобами комунікації: жестами, мімікою, опорою на графічні зображення. У цих дітей наявні окремі рухові дії (захоплення, утримання предмета, контрольовані руху шиї тощо), що створює передумови для навчання виконувати доступні операції самообслуговування i предметно-практичної діяльності. Застосування спеціальних електронних i механічних пристроїв, програмного забезпечення для персонального комп'ютера дає можливість навчати таких дітей користуватися різною технікою.

II) Діти зі складними порушеннями емоційно-вольової сфери та регуляції поведінки потребують постійного контролю з боку дорослих. Контакт із оточенням відсутній або виникає у формі фізичного звернення до дорослих зазвичай у ситуаціях, коли потрібна допомога в задоволенні потреби. Такі діти не виявляють інтерес до діяльності інших, часто не виконують прохання чи інструкції, на заборону, велику 
скупченість людей чи шум реагують агресією або самоагресією. Моторні функції рук у них не порушені, але предметні дії формуються важко через слабку мотивацію діяльності. Аутистичні риси особистості таких дітей часто ускладнюють встановлення глибини порушення їхнього інтелектуального розвитку. Особливості їхніх емоційновольових якостей, аутистичні риси їхньої поведінки зумовлюють труднощі у груповому навчанні. Такі особливості вимагають організації індивідуальної педагогічної роботи 3 метою подальшої адаптації до навчання за умов групи. Збереження (здебільшого) моторних функцій дітей робить можливим навчання предметнопрактичної діяльності. Індивідуальний диференційований підхід дозволяє спочатку формувати предметно-маніпулятивну діяльність, потім - уміння використовувати предмети за призначенням, розвивати предметну діяльність у процесі виконання серій вправ із різними об'єктами, навички виконання побутових і трудових операцій.

III) Діти 3 помірною та глибокою розумовою відсталістю, в поєднанні з більш легкими формами інших порушень, ніж у двох вищеназваних випадках. Такі діти не потребують постійної допомоги та контролю з боку дорослих, вони можуть мати порушення загальної моторики, але пересуваються самостійно. Їхня моторна недостатність проявляється в уповільненому темпі, несформованій координації та неточності рухів. У деяких дітей спостерігається стереотип, небажання контактувати 3 оточуючими та інші аутистичні риси, подібні 3 характеристикою дітей попередньої групи. Серед їхніх клінічних діагнозів переважає олігофренія від легкого до глибокого ступеня. Більшість дітей із названої групи мають елементарні навички спілкування. Порівняно з дітьми попередніх груп у них зазвичай проявляються більш розвинені комунікативні функції, бажання спілкуватися. Діти, які володіють вербальним мовленням, можуть звернутися до оточення і висловити своє бажання, повідомити про виконане завдання, відповісти на питання дорослого на рівні слова, словосполучення або простого речення. Деякі діти не володіють вербальним мовленням, але можуть вступати в контакт і здійснювати елементарне спілкування за допомогою жестів, вокалізації чи окремих складів і слів. Діти цієї групи можуть виконати окремі операції предметних дій, але серед якісних показників діяльності переважає слабка мотивація, короткочасність концентрації уваги, непослідовність виконуваних операцій, що перешкоджає виконанню цілісного дії. Успішність навчання таких дітей предметної, побутової та доступної трудової діяльності різні. Результативність навчання визначається фізичним та інтелектуальним розвитком дітей. За відсутності парезів рук і за відповідної інтелектуальної готовності діти цієї групи опановують окремі навички побутової (прання, прасування, підмітання, приготування їжі) та трудової діяльності (операції деревообробки, 
рослинництва, шиття, поліграфії тощо). На відміну від дітей попередньої групи, більшість із них можуть короткий час здійснювати спільну діяльність 3 іншими людьми, що служить передумовою для їхного навчання у групі. Загалом у них спостерігається більш високий рівень розвитку соціально значущих уявлень, умінь і навичок ${ }^{22}$.

Аналізуючи психологічні особливості розвитку дітей зі складними множинними порушеннями розвитку, М. Жигорєва поділяє їх на низький, середній і вище середнього рівні. Діти низького рівня психічного розвитку характеризуються стійкими порушеннями психічної діяльності у сфері соціальної взаємодії, розвитку когнітивних процесів і мовлення. Більшість таких дітей мають формальний контакт iз дорослими або взагалі відмовляються від будь-якої комунікації. Така пасивність i слабкий соціальний інтерес уповільнює розвиток комунікативних навичок дитини. Тривалий час діти залишаються на емоційно-особистому рівні спілкування, у них переважає тілесний контакт, експресивно-мімічні прояви, окремі вокалізації. Наслідувальні дії практично не формуються. Саморегуляція та контроль відсутні, діти інертні, допомогу не сприймають. Вони можуть працювати спільно 3 педагогом чи психологом. Зона найближчого розвитку дітей першого (низького) рівня дуже звужена.

До середнього рівня розвитку віднесено найбільшу кількість дітей. Порушення виявляються у нерівномірну розвитку різних психічних процесів. Для дітей характерна недостатність наочно-образного, наочно-дійового мислення та низький рівень словесно-логічного мислення. Діти не володіють аналізом, синтезом і порівнянням. Увага недостатньо стійка, моторика відстає у розвитку, що проявляється у моторній незграбності та недостатній координації, відзначається порушення емоційно-вольової сфери. Діти зі складними порушення такого рівня більш перспективні в плані розвитку та інтеграції у суспільство, у них проявляється адекватність поведінки, вони енергійні у своїх діях порівняно із дітьми попередньої групи.

Діти вище середнього рівня порівняно рано привчаються до соціальних норм i правил, достатньо оволодівають навичками самообслуговування, комунікації та ігровими діями. Спільною для них $\epsilon$ недостатня сформованість узагальнення й абстрагування, але аналіз і синтез розвинуті, тому діти застосовують їх для вирішення нескладних задач, тобто вони здатні до переносу засвоєних умінь і навичок у різних ситуаціях. У процесі самостійної діяльності під час виконання завдань використовуються залишки зору та слуху. У дітей цього рівня увага, емоційно-вольова сфера більш стійкі, емоційні прояви адекватні та різноманітні, спостерігається урівноваженість

22 Обучение детей с тяжелыми и множественными нарушениями развития: Программы / под ред. А.М. Царева. Псков, 2004. 132 с. 
процесів збудження та гальмування, що дає їм змогу регулювати свою поведінку. Відсутність або часткова втрата зору, слуху, порушення опорно-рухової системи, затримка психічного розвитку спостерігаються у дітей зі складними порушеннями цього рівня, що суттєво порушує пізнання навколишнього світу та планомірності формування мови. Характер діяльності дітей цього рівня більш цілеспрямований, довільно керуючий i мотивований. Для дитини $€$ значимим досягнення нею певного результату своєї діяльності. Такі діти правильно розуміють ситуацію, $є$ чутливими до похвали чи дорікань, керують своєю діяльністю й адекватно сприймають надану їм допомогу ${ }^{23}$.

Незважаючи на те, що діти, які належать до вищезазначених рівнів засвоєння освітнього стандарту, $\epsilon$ складними у плані навчання й адаптації, можливість перебування їх у звичайному класі загальноосвітньої школи не $\epsilon$ протиправною. Для дитини зі складним порушенням розвитку дитячий колектив $є$ потужним і ледь не єдиним ресурсом для розвитку. Спільне навчання таких дітей є позитивним, оскільки діти навчаються взаємодіяти один з одним, для здорових дітей присутність у класі дітей зі слабкими порушеннями також $\epsilon$ сприятливим фактором формування їхньої толерантності.

Відповідно до загального рівня готовності дитини зі складними множинними порушеннями розвитку до освітньої інтеграції визначено такі іiї варіанти: постійне, постійне неповне, часткове, епізодичне чи дистанційне навчання. Досвід роботи 3 дітьми із складними порушеннями показує, що зазвичай для інтеграції таких дітей обирається тимчасова (часткова інтеграція або епізодична), тобто такі учні об'єднуються з дітьми без вад розвитку для проведення спільних заходів (свят, конкурсів, виставок дитячих робіт, шкільних гуртків). Варіант інтеграції та режим відвідування вирішується на психологомедико-педагогічному консиліумі на підставі аналізу документів і попереднього психолого-педагогічного обстеження дитини.

Дослідження Н. Александрової, Ю. Антибури, Г. Арістової, Т. Басилової, Г. Бертинь, М. Блюміної, М. Вернадської, Л. Виготського, Т. Власової, Н. Гладких, Л. Головчиц, Л. Григорьєвої, М. Давидова, М. Жигоревої, Н. Зінов'євої, І. Каткової, О. Каракулової, К. Козлової, В. Лубовського, О. Мастюкової, Н. Медової, А. Мещерякова, I. Молчановської, О. Московкіної, А. Набичевої, Д. Науменко, М. Певзнер, Л. Переслені, Т. Розанової, Н. Сошнікової, І. Філатової, Л. Фільцикової, В.Чулкова, Л. Яковлевої, D. Boas, L. Ferreira, M. Moura, S. Maia, I. Amaral, M. Janssen, D. Moores, J. Van Dijk засвідчили, що

${ }^{23}$ Жигорева М.В., Левченко И.Ю. Дети с комплексными нарушениями развития: Диагностика и сопровождение. Москва : Национальный книжный центр, 2016. $208 \mathrm{c}$. 
у клінічній картині комплексних порушень розвитку у дітей значне місце займає виражена інтелектуальна недостатність, яка виступає у різних поєднаннях із порушеннями опорно-рухового апарату (дитячий церебральний параліч різної форми і ступеня тяжкості), важкими порушеннями мови, порушеннями функцій аналізаторних систем (зір, слух), розладами емоційно-вольової сфери, аутистичними розладами. Інтелектуальна недостатність (за МКХ-10: F-71 - помірна, F-72 - важка, F-73 - глибока), як можливий компонент комплексного порушення розвитку значно знижує компенсаторні можливості розвитку дитини, але не визначає їхню неможливість. Загальною закономірністю, що впливає на подальший розвиток таких дітей, $є$ умови раннього розвитку дитини. Наявність двох і більше порушень розвитку значно зменшує контакт дитини з оточенням.

Такими дослідниками, як Л. Григор'єва, 3. Алієва, М. Бернадська, Н. Благосклонна, Л. Рожкова, В. Толстова, Л. Фільчикова, М. Фішман було вивчено проблему особливостей психофізіології розвитку когнітивних процесів у дітей із комплексними порушеннями розвитку. Було встановлено системний характер змін інтегративної діяльності мозку внаслідок зорової, слухової та бісенсорної деривації. Поруч із порушеннями функціонування аналізаторів було виявлено переважання механізмів дифузної неспецифічної активації. Сенсорний дефіцит призводить до уповільнення дозрівання системи керування активації мозку. Доведено, що у молодших школярів дефіцит уваги зумовлений недостатністю цих процесів через дисфункцію стовбурових структур мозку та таламо-коркових зв'язків. Порушення пам'яті поєднувалося із недостатністю системних асоціативних i регуляторних процесів. Нейропсихологічні характеристики інтегративної діяльності мозку слід ураховувати у розробці психолого-педагогічних стратегій навчання дітей із комплексними порушеннями розвитку ${ }^{24}$.

Діти зі складними множинними порушеннями розвитку вимагають постійної, інтенсивної допомоги, яка надається постійно і в більш ніж одній життєво важливій «лінії» діяльності. Без такої підтримки участь дітей цієї категорії у соціокультурному житті суспільства, в інтеграційних процесах, які доступні іншим людям, неможливо. Основним засобом підтримки дітей зі складними множинними порушеннями розвитку вважається спеціальна психолого-педагогічна допомога, що комплексно здійснюється різними фахівцями в тісній співпраці із сім'єю або законними представниками, котрі виховують дитину зі складними множинними порушеннями розвитку.

24 Григорьева Л.П., Алиева 3.С., Бернадская М.Э., Благосклонова Н.К., Костина Т.Ф., Рожкова Л.А., Толстова В.А., Фильчикова Л.И., Фишман М.Н. Проблемы психофизиологии развития познавательных процессов у детей со слодными нарушениями. Дефектология. 2002. № 4. С. 12. 


\section{ВИСНОВКИ}

Чисельність дітей із комплексними порушеннями розвитку зростає щороку. Основою для їх визначення $\epsilon$ поліморфний характер вад розвитку.

Сукупність інтелектуального, сенсорного, перцептивного чи рухового порушень розвитку провокує відхилення у всіх видах когнітивної діяльності. Знижується обсяг і якість інформації, яку дитина отримує. Інтелектуальне недорозвинення характеризується стійкими порушеннями всієї психічної діяльності загалом, а також іiі нерівномірними змінами. Одні психічні процеси виявляються чітко недорозвиненими, а інші залишаються відносно збереженими. Первинний дефект за інтелектуальної недостатності зумовлює виникнення вторинних і третинних відхилень у розвитку. За умов сенсорної, культурної, міжособистісної депривації в сенситивні періоди розвитку така дитина не отримує і не накопичує в достатній кількості чуттєво-емоційної та наочної інформації про навколишній світ без спеціально організованого навчання і виховання. Це призводить до недорозвинення як окремих функцій i процесів (предметних дій, формування образів предметів, просторової орієнтації та моторики, емоційно-чуттєвого контакту з дорослими та спілкування), так і до загальної затримки психічного розвитку.

Таким чином, діти 3 комплексними порушеннями розвитку мають специфічні особливості психічного розвитку: уповільнений розвиток відчуттів і сприймань, обмеженість предметних уявлень, затримку розвитку загальної моторики, недорозвиток дрібної моторики, порушення зорово-моторної координації, недостатність просторових уявлень, сповільнений розвиток різних форм діяльності, недорозвиненість мовлення, затримку розвитку мислення, певні особливості емоційно-вольової сфери, міміки та пантоміміки, на відміну від дітей з одиничними порушеннями.

\section{АНОТАЦІЯ}

Дослідження присвячено аналізу наукових підходів до розуміння комплексних порушень розвитку дітей i характеристиці їхніх психологічних особливостей. На основі поліморфного характеру порушення в розвитку дитини часто називають «складними», «бісенсорними», «потрійними», «провідними порушеннями із супутніми», «ускладненими», «множинними», «комплексними порушеннями розвитку». Проаналізовано такі зарубіжні аналоги порушеного розвитку, як «handicap», «disability», «handicapped children», «severely profoundly handicapped», «complex impairments», «multiply impairments», «additional disabilities», «impairment». До комплексних порушень відносять поєднання двох і більше первинних психофізичних порушень, що однаковою мірою визначають структуру 
дизонтогенезу та складнощі соціальної адаптації дитини. Такі порушення зумовлюють відхилення від нормального розвитку та пов'язані з порушеннями різних систем, кожне з яких існує у цьому комплексі 3 характерними для нього особливостями. На підставі аналізу психологічних особливостей розвитку дітей із комплексними порушеннями виділяють такі їхні групи: зі складними вадами опорнорухового апарату, які самостійно не пересуваються; діти зі складними порушеннями емоційно-вольової сфери та регуляції поведінки; діти 3 помірною та глибокою розумовою відсталістю. Такі категорії дітей потребують постійної допомоги дорослих та індивідуального підходу.

\section{ЛІТЕРАТУРА}

1. Басилова Т.А., Александрова Н.А. Как помочь малышу со сложным нарушением развития. Москва : Просвещение, 2008. С. 20.

2. Блюмина М.Г. Распространенность, этиология и некоторые особенности клинических проявлений сложных дефектов. Дефектология. 1989. № 3. С. 3-10.

3. Выготский Л.С. Проблемы дефектологии. Москва : Просвещение, 1995. 527 с.

4. Гладких Н.В. Актуальні проблеми навчання та виховання дітей 3 комплексними порушеннями розвитку в Україні. Науковий часопис імені М.П. Драгоманова. Серія 19. Корекційна педагогіка та спеціальна психологія. 2014. № 26. С. 52-57.

5. Григорьева Л.П., Алиева 3.С., Бернадская М.Э., Благосклонова Н.К., Костина Т.Ф., Рожкова Л.А., Толстова В.А., Фильчикова Л.И., Фишман М.Н. Проблемы психофизиологии развития познавательных процессов у детей со сложными нарушениями. Дефектология. 2002. № 4. С. 3-14.

6. Дитячі проблеми. URL: http://uwcfoundation.com/ua/detskieproblemyi (дата звернення: 28.10.2020).

7. Жигорева М.В., Левченко И.Ю. Дети с комплексными нарушениями развития: Диагностика и сопровождение. Москва : Национальный книжный центр, 2016. 208 с.

8. Иванова Т.Б., Илюхина В.А., Кошулько М.А. Диагностика нарушений в развитии детей с ЗПР. Санкт-Петербург : Детство-Пресс, 2011. 112 с.

9. Модель комплексного сопровождения детей с тяжелыми множественными нарушениями развития, в том числе с расстройствами аутистического спектра : методическое пособие / авт.-сост. И.А. Филатов, Е.В. Каракулова. Екатеринбург : УГПУ, 2017. 287 с.

10. Наказ MO3 України № 981 від 23 травня 2018 р. «Про затвердження перекладу Міжнародної класифікації функціонування, обмежень життєдіяльності та здоров'я та Міжнародної класифікації функціонування, обмежень життєдіяльності та здоров’я дітей 
і підлітків». URL: http://search.ligazakon.ua/1_doc2.nsf/link1/ MOZ30749.html (дата звернення: 28.10.2020).

11. Обучение детей с тяжелыми и множественными нарушениями развития: Программы / под ред. А.М. Царева. Псков, 2004. 132 с.

12. Розанова Т.В. Методы психолого-педагогического изучения глухих детей со сложным дефектом. Дефектология. 1992. № 2-3. C. $5-11$.

13. Статистичні дані. Міністерство освіти і науки України - $\mathrm{MOH}$. URL: mon.gov.uarstatistichni-dani (дата звернення: 28.10.2020).

14. Чулков В.Н. Развитие и образование детей со сложными нарушениями развития. Специальная педагогика : учебное пособие / под ред. Н.М. Назаровой. Москва : Academia, 2000. С. 332-344.

15. Boas D.C., Ferreira L., Moura M., Maia S., Amaral I. Analysis of interaction and attention processes in a child with multiple disabilities. Audiology - Communication Research. 2017. 12. URL: https://doi.org/10.1590/2317-6431-2016-1718.

16. Marzouq A.A. The Importance of Teachers' Universal Design for Transition Principles Knowledge in Preparing Students Who Are Deaf and Hard of Hearing for the Life after School in Saudi Arabia. Creative Education. 2018. Vol. 9. № 3. DOI: 10.4236/ce.2018.93036.

17. Moores D.F. Education the deaf: psychology, principles and practices. Boston, 1987. $143 \mathrm{p}$.

18. Van Dijk J., Janssen M. Deafblind children. In H. Nakken (Ed.), Meervoudig gehandicapten. Rotterdam : Lemniscaat, 1993. P. 34-73.

\section{Information about the authors: Shevchuk V. V.,}

$\mathrm{Ph} . \mathrm{D}$. in Psychology Sciences, Associate Professor at the Department of Psychology Poltava V. G. Korolenko National Pedagogical University 2, Ostrohradsky str., Poltava, 36000, Ukraine

Klymenko Yu. O., $\mathrm{Ph} . \mathrm{D}$. in Psychology Sciences, Associate Professor at the Department of Psychology Poltava V. G. Korolenko National Pedagogical University 2, Ostrohradsky str., Poltava, 36000, Ukraine 